\title{
The Efficiency of the Triple P Program for Parents of Children with Type-1 Diabetes
}

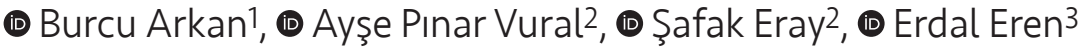 \\ 1Uludağ University Faculty of Health Sciences, Department of Psychiatric Nursing, Bursa, Turkey \\ 2Uludağ University Faculty of Medicine, Department of Child Psychiatry, Bursa, Turkey \\ 3Uludağ University Faculty of Medicine, Department of Pediatrics, Division of Endocrinology, Bursa, Turkey
}

\begin{abstract}
Aim: The aim of this study was to investigate the effect of the Triple P-Positive Parenting Training Program, which was applied to the parents of children and adolescents with a type 1 diabetes (T1D) diagnosis aged 3-12 years, on parental attitude, parental mental health, and child behaviour.

Materials and Methods: This research was conducted in a quasi-experimental manner. The sample of the research consisted of 32 parents who had children with a T1D diagnosis aged 3-12 years and who agreed to participate in the study. Data were collected using the Family Background Questionnaire, General Health Questionnaire, Strengths and Difficulties Questionnaire, Parental Attitude Research Instrument, Conflict Behaviour Questionnaire and Parent Satisfaction Questionnaire. The Group Triple P Programme was implemented with all groups for 8 weeks. Data were collected immediately after the programme. Data were evaluated by using multidirectional variance analysis, t- test and chi-square test.

Results: It was shown that the Group Triple P applied to the parents of those children with a T1D diagnosis positively affects the mental health of the parents, their parental attitudes and the problematic behaviour of their children and also that the parents had less conflict with their children and the children had less conflict with their parents.

Conclusion: It is suggested that further studies are carried out in different centres and cities with the Group Triple P Programme to widen the use of the Group Triple P Programme and also to plan future research where the Group Triple P programme and other programmes currently used in country can be compared.
\end{abstract}

Keywords: Group Triple P Programme, behavioural problems, parenting style, parental mental health, type 1 diabetes

\section{Introduction}

Developments in the fields of health and technology over the past 20 years have led to an increase in the number of children who have a chronic disease (1-4). Diabetes has become one of the most common chronic diseases among children as its incidence has increased (5). It is estimated that 70,000 children under the age of 15 years develop type 1 diabetes (T1D) each year (6). Moreover, in the United States, it is reported that 400-600 children are diagnosed with T1D annually.

T1D management is a time-consuming, complex, and difficult process. Diabetes requires continuous and careful treatment management throughout life (7). Effective diabetes management involves paying attention to diet and exercise, monitoring blood glucose levels during the day, injecting insulin or using an insulin pump, and being 
able to respond to urgent medical conditions (8). Parents are fully or primarily responsible for diabetes management in children depending on the child's age $(9,10)$. The results obtained in studies suggest that the responsibility of diabetes management should be gradually transferred to children under the parents' supervision until these children or adolescents take the responsibility of primary treatment alone (3,11-13).

Parents have a very important role in their children's diabetes management; however, efficient T1D management requires the cooperation of both parents and children (1214). Non-compliance to treatment may lead to negative short- and long-term consequences for a child's health and poor management of diabetes can cause serious health complications (9).

Parent-related and family-related factors affect the compliance to treatment and glycaemic control levels of children with T1D. The children of extremely indulgent families $(9,15-17)$ and families with conflicts and authoritarian parents $(9,13,18)$ have less child welfare, lower self-efficacy, increased depression, and increased behavioural problems (19). On the other hand, families with effective communication and democratic attitudes increase the compliance to treatment in their children and diabetes management is handled more successfully $(9,15)$. As opposed to the disease-related factors that cannot be changed (for example, the age of disease onset and the severity of the disease), parenting can be changed and good parenting practices can be developed.

Studies have shown the effectiveness of interventions to reduce family conflicts and increase family communication and child welfare for children with diabetes $(9,12,13)$.

Triple P-Positive Parenting Program is the most effective parent program in the world. It cooperates with families and society, reduces risk factors, supports protective factors, has a multidisciplinary approach, has high evidence standards, uses randomized controlled studies, and obtains long-term results. $(9,20,21)$. The theoretical structure of the program is based on social learning principles and cognitive theory. The program aims to create a positive relationship between the child and the parents, to develop positive parenting skills, to support the child's talents and development, to enable the child to gain skills for the management of problematic behaviours, to teach effective communication skills to couples, and to reduce parental stress (21-24). Strong evidence regarding the efficiency of preventive and clinical interventions presented in various ways has been obtained in randomized controlled and meta-analysis studies conducted on the Triple P-Positive Parenting Program (25-29).

A limited number of studies on the Triple P-Positive Parenting Program have been conducted regarding the parents of children with a T1D diagnosis. In the randomized controlled study conducted by Westrupp et al. (30) with 76 parents, it was determined that the parents had better mental health, the problematic behaviours of children decreased, and there was no change in glycaemic control levels after the Triple P-Positive Parenting Program (30). In another study conducted by Doherty, Calam, and Sanders, it was found that family conflicts, especially disease-related ones, decreased after the Triple P-Positive Parenting Program applied to the parents of adolescents aged between 11-17 years with T1D (31).

According to the results obtained from these studies conducted with different samples in Turkey, it was determined that there was a need to carry out studies with the Triple P-Positive Parenting Program at different clinics and schools (32-35). When the studies conducted regarding the Triple P-Positive Parenting Program in Turkey so far were considered, it was seen that there was no study conducted based on families with diabetic children. Furthermore, the number of studies conducted in other countries is quite limited.

In our country, there is a need for the implementation of the Triple P-Positive Parenting Program that will meet the needs of parents and that will be easily accessed by every walk of life and to extend this program by making it functional.

The aim of this study was to investigate the effect of the Triple P-Positive Parenting Program, which was applied to the parents of children and adolescents aged 3-12 years with a T1D diagnosis, on parental attitude, parental mental health, and child behaviour.

\section{Materials and Methods}

A "Single Group Pre-test/Post-test Model", one of the quasi-experimental designs, was used to evaluate the effect of the Triple P-Positive Parenting Program, which was applied to the parents of children aged 3-12 years with a T1D diagnosis in a university hospital in Bursa, on parental attitude, parental mental health, and child behaviour.

The study was conducted together with Uludağ University Hospital Child and Adolescent Mental Health Clinic and Clinic of Paediatric Endocrinology. The training sessions were held between December 2014 and January 2015. 
The sample of the research consisted of 32 parents who had children aged 3-12 years with a T1D diagnosis and who agreed to participate in the study after the necessary explanations were made without any sampling method.

The inclusion and exclusion criteria of the study were taken into account while selecting the parents. In this respect, the sample characteristics can be explained as follows:

- Parents of children with T1D

- Parents of children without mental retardation, autism, psychosis, schizophrenia, bipolar disorder, obsessivecompulsive disorder or diffused developmental disorder

- Parents living with their child (both mother and father or only the mother or father)

- Non-divorced parents, parents living together

- Parents who have not received any mental assistance for parenting education

- Parents who read the informed consent form and who wanted to participate in the study

Written permission for this study (decision number: 2013-14/19) was obtained from the Ethics Committee of Bursa Uludağ University Hospital. In the research, the parents were informed that the data obtained would be reported without giving a name to protect their privacy and that their names would be kept confidential.

\section{Data Collection Tools}

Socio-demographic Data Collection form: This form consists of 19 questions regarding the parents' families, education and occupation and information about the health status of the parent and child.

Parental Attitude Research Instrument: The scale was developed by Schaefer and Bell (1958) in order to determine the child-rearing attitudes of parents and adapted to Turkish by LeCompte et al. (36). The scale can be applied to parents, children, and adolescents. It consists of 60 items and 5 subdimensions. High scores indicate that the respondent supports the attitude expressed in the relevant subdimension. High scores obtained from other subdimensions except for democratic approach/ensuring equality indicates a negative parental attitude. When an evaluation was made in terms of psychometric characteristics, the scale was repeatedly applied to a group of 34 female students at three-week intervals for the test-retest reliability of the scale and the Spearman Correlation coefficients were found to be between 0.58 and 0.88 . The scale was then applied to 179 mothers from three socio-economic levels, low, middle, and high. As a result of the analysis conducted, it was determined that each subdimension had a high internal consistency and that the half alpha internal consistency was 0.64. As a result of factor analysis, four factors were identified and a fifth factor was identified from the rest of the items. In the final form of the scale, the internal consistency of the subdimensions ranged between 0.59 (democratic approach/ensuring equality subdimension) and 0.90 (strict discipline subdimension). For the factor validity of the scale, the correlation between the mothers' socioeconomic levels and 5 factors was examined. Accordingly, there was a negative correlation found between SEL and the extreme motherhood/overprotection and the strict discipline subdimensions and a positive correlation between SEL and the other factors (36).

Strengths and Difficulties Questionnaire: The Strengths and Difficulties Questionnaire (SDQ) was developed by Robert Goodman in 1997 and is used to screen mental problems in children and adolescents. The Turkish validity and reliability study of the scale was conducted by Güvenir et al. (37). This questionnaire includes a parent and teacher form for those aged 4-16 years and an adolescent form, which is filled out by the adolescent by him/herself, for those aged 11-16 years. The SDQ consists of 25 questions, some of them regarding positive and some of them regarding negative behaviour characteristics. These questions are divided into 5 sub-problem areas. These behavioural problems are as follows: Attention deficit and hyperactivity, emotional problems, peer problems, and social behaviours. As a result of the SDQ scoring, subscores specific to these problem areas can be obtained as well as the total score. The SDQ includes items that question psychiatric symptoms and the level of exposure to these symptoms. In this section, the respondent evaluates whether the adolescent has difficulty with their emotions, behaviours, attention, and relationships with others. If one's response indicates difficulty, the person reports whether this difficulty puts the child and adolescent into distress, whether it affects their daily life, whether it challenges people who live together, and how long the difficulties have existed (37).

General Health Questionnaire-12: The General Health Questionnaire is a questionnaire that is used as a primary screening test in social studies examining mental diseases. The 12-question General Health Questionnaire is extensively preferred since it is short, has high sensitivity and specificity in distinguishing cases and can be used in various sociocultural environments (38). The Turkish validity and reliability study was conducted by Kilic (1996). The lowest score that 
can be obtained from this scale is 0 and the highest score is 12. Higher scores indicate a higher risk of mental disease. A score of 2 points or more in the 12-item form of the general health questionnaire indicates a high possibility of having a psychiatric disorder. In the literature, the concepts of "distress", "well-being", and "mental health" are assessed using the general health questionnaire (38).

Conflict Behaviour Assessment Questionnaire: The questionnaire was developed by the researcher by reviewing the literature to investigate the conflict behaviours of the children towards their parents and of the parents towards their children (39). For the content validity of the form prepared, the opinions of 3 experts, one faculty member of psychiatry nursing and two child and adolescent psychiatry physicians, were obtained. The questionnaire was finalized considering their feedback. It consists of a parent form (20 items) and a child form (20 items for the mother, 20 items for the father). Each item has two options, "yes" and "no". Both options cause a score increase in some items. A high score indicates that many conflicts are experienced between the child and his/her parent in both directions and that they do not show appropriate behaviour during the conflict (39).

Satisfaction Questionnaire: This questionnaire was prepared by the researcher by reviewing the literature in order to determine the opinions and satisfaction levels of the parents after the Triple P-Positive Parenting Program (39). For the content validity of the form prepared, the opinions of 3 experts, one faculty member of psychiatry nursing and two child and adolescent psychiatry physicians, were obtained. The questionnaire was finalized considering the feedback from these expert opinions. It consists of 14 items, 11 closed-ended and 3 open-ended. The highest score that can be obtained from the questionnaire is 77 and the lowest score is 11. A high score indicates the parents' satisfaction with the Triple P-Positive Parenting Program (39).

HbA1C Level: HbA1C levels of the children with T1D were obtained from laboratory results before and after the Triple P-Positive Parenting Program.

\section{Intervention Program}

The Triple P-Positive Parenting Program provides specific information that helps parents who participate in the program to encourage the development of their children, reduce problematic behaviours, and reduce or eliminate risky situations that endanger the health of the child. The program, which is organized for the parents of children aged 0-12 years, consists of 8 sessions. First, four two-hour group sessions are held for groups of 10-12 parents. After these sessions, three 15-30 minute-phone calls are conducted with each parent and a final closing session is held (Session 8). Follow-up phone calls provide additional support to parents who implement what they have learned in the group sessions. The closing group session allows parents to assess their progress and share their achievements. Both parents (when conditions are appropriate) are encouraged to participate $(21,22,24)$.

\section{Statistical Analysis}

The data were evaluated using the 22.00 SPSS package software. The significance level (Type1Error) was determined to be 0.05 in this study. The t-test was used to assess the effect of the intervention on dependent groups.

\section{Results}

The descriptive characteristics of the parents included in the research are given in Table I.

The parents scored 40.09 points from the Overprotection subdimension of the Parental Attitude Research Instrument (PARI) before the Triple P-Positive Parenting Program and 35.27 points after the program; 29.41 points from the Democratic Approach/Ensuring Equality subdimension before the training and 33.01 points after the training; 14.18 points from the Marriage Conflict subdimension before the training and 12.07 points after the training; 34.66 points from the Strict Discipline subdimension before the training and 30.86 after the training (Table II).

There was a statistically significant difference found between the pre- and post-training mean scores from the subdimensions of overprotection ( $t=5.62 p=0.000)$, Democratic Approach/Ensuring Equality $(t=3.41 p=0.001)$, Marriage Conflict ( $t=2.98 p=0.000)$, Strict Discipline $(t=4.24$ $p=0.000)$. On the other hand, from the Denial of Housewife Roles subdimension, the parents scored 28.79 before the training and 27.23 after the training. When the pre- and post-training mean scores from the Denial of Housewife Roles subdimension ( $t=-0.72 p=0.52$ ) were compared, there was no statistically significant difference found (Table II).

The score obtained from the SDQ was 15.81 before the Triple P-Positive Parenting Program and 10.01 after the program. According to the result of the t-test which was conducted to evaluate whether there was a difference between the scores of the adolescents from the SDQ before and after the program, the difference between the two mean scores was found to be statistically significant ( $t=7.79$ $\mathrm{p}=0.000$ ) (Table III). 
The score of the parents obtained from the general health questionnaire was 5.45 before the Triple P-Positive Parenting Program and 2.19 after the program. According to the result of the t-test which was conducted to evaluate

Table I. Descriptive characteristics of parents included in the research

\begin{tabular}{|l|l|l|}
\hline Variables & Number & $\%$ \\
\hline Age & \multicolumn{2}{|l|}{} \\
\hline $25-35$ years & 18 & 56.3 \\
\hline $36-45$ years & 11 & 34.4 \\
\hline $46-55$ years & 3 & 9.3 \\
\hline $56-65$ years & - & \\
\hline
\end{tabular}

\section{Educational status}

\begin{tabular}{|l|l|l|}
\hline Primary school graduate & 4 & 12.5 \\
\hline Secondary school graduate & 10 & 31.3 \\
\hline High school graduate & 15 & 46.9 \\
\hline University graduate & 3 & 9.3 \\
\hline Post-graduate & - & \\
\hline
\end{tabular}

\section{Occupational status}

\begin{tabular}{|l|l|l|}
\hline Housewife & 8 & 25 \\
\hline Government employee & 10 & 31.3 \\
\hline Retired & 2 & 6.2 \\
\hline Worker & 11 & 34.4 \\
\hline Unemployed & 1 & 3.1 \\
\hline
\end{tabular}

\section{Health status of parents}

\begin{tabular}{|l|l|l|}
\hline I received help in the last 6 months & 21 & 65.6 \\
\hline I did not receive help in the last 6 months & 11 & 34.4 \\
\hline
\end{tabular}

Previous participation in a parenting training program

\begin{tabular}{|l|l|l|}
\hline Yes & 0 & 0 \\
\hline No & 32 & 100 \\
\hline TOTAL & 32 & 100 \\
\hline
\end{tabular}

whether there was a difference between the scores of the parents from the general health questionnaire before and after the program, the difference between the two mean scores was found to be statistically significant ( $t=5.54$ $\mathrm{p}=0.000$ ) (Table III).

The score of the parents obtained from the conflict behaviour questionnaire was X:13.18 before the Triple P-Positive Parenting Program and X:10.09 after the program. According to the result of the t-test which was conducted to evaluate whether there was a difference between the scores of the parents from the conflict behaviour questionnaire before and after the program, the difference between the two mean scores was found to be statistically significant $(\mathrm{p}<0.05)$ (Table III).

The score of the children obtained from the conflict behaviour questionnaire was X:14.10 before the Triple P-Positive Parenting Program and X:11.45 after the program. According to the result of the t-test which was conducted to evaluate whether there was a difference between the scores of the adolescents from the conflict behaviour

Table II. Mean scores of parents from the parental attitude research instrument subdimensions before and after the program

\begin{tabular}{|l|l|l|l|l|}
\hline $\begin{array}{l}\text { Parental attitude } \\
\text { research } \\
\text { instrument } \\
\text { subdimensions }\end{array}$ & $\begin{array}{l}\text { Pre-test } \\
\mathbf{X} \pm \text { SD }\end{array}$ & $\begin{array}{l}\text { Post-test } \\
\mathbf{X} \pm \text { SD }\end{array}$ & $\mathbf{t}$ & $\mathbf{p}$ \\
\hline Overprotection & $40.09 \pm 8.31$ & $35.27 \pm 6.04$ & 5.62 & 0.000 \\
\hline $\begin{array}{l}\text { Democratic } \\
\text { approach/ensuring } \\
\text { equality }\end{array}$ & $29.41 \pm 3.15$ & $33.01 \pm 3.12$ & 3.41 & 0.001 \\
\hline $\begin{array}{l}\text { Denial of housewife } \\
\text { roles }\end{array}$ & $28.79 \pm 6.49$ & $27.23 \pm 6.60$ & -0.72 & 0.52 \\
\hline Marriage conflict & $14.18 \pm 3.67$ & $12.07 \pm 3.77$ & 2.98 & 0.000 \\
\hline Strict discipline & $34.66 \pm 6.52$ & $30.86 \pm 6.76$ & 4.24 & 0.000 \\
\hline SD: Standard deviation & & & & \\
\hline
\end{tabular}

Table III. Mean scores of parents from the questionnaires before and after the program $(n=32)$

\begin{tabular}{|l|l|l|l|l|}
\hline Questionnaires & $\begin{array}{l}\text { Pre-test } \\
\text { X } \pm \text { SD }\end{array}$ & $\begin{array}{l}\text { Post-test } \\
\text { X } \pm \text { SD }\end{array}$ & t & P \\
\hline Strengths and difficulties questionnaire & $15.81 \pm 5.90$ & $10.01 \pm 2.53$ & 7.79 & 0.000 \\
\hline General health questionnaire & $5.45 \pm 3.18$ & $2.19 \pm 2.63$ & 5.54 & 0.000 \\
\hline Conflict questionnaire (parent) & $13.18 \pm 3.92$ & $10.09 \pm 2.27$ & 5.80 & 0.000 \\
\hline Conflict questionnaire (adolescent) & $14.10 \pm 2.95$ & $11.45 \pm 1.88$ & 8.25 & 0.000 \\
\hline Satisfaction questionnaire & - & $73.80 \pm 2.87$ & - & - \\
\hline HbA1C (mmole/mole) & 8.17 & 7.92 & -0.43 & 0.338 \\
\hline SD: Standard deviation & & & \\
\hline
\end{tabular}


questionnaire before and after the program, the difference between the two mean scores was found to be statistically significant $(\mathrm{p}<0.05)$ (Table III).

The HbA1C value of the children was 8.17 before the Triple P-Positive Parenting Program and 7.92 after the program. When pre- and post-training HbA1C values were compared, no statistically significant difference was found ( $\mathrm{t}=-0.43 \mathrm{p}=0.338$ ) (Table III).

The parents' level of satisfaction with the Triple P-Positive Parenting Program was 73.80 out of a total score of 77 (Table III).

\section{Discussion}

In this study, the Triple P-Positive Parenting Program applied to the parents of children with T1D led to a significant improvement in the parental attitudes and mental health levels of these parents, by reducing the problematic behaviours of children and by reducing family conflicts.

In this study, when the difference in the PARI score after the Triple P-Positive Parenting Program was evaluated, it was found that there was a significant decrease in the subdimensions of Overprotection, Democratic Approach/ Ensuring Equality, Marriage Conflict, and Strict Discipline. However, there was no difference was found in the Denial of Housewife Roles subdimension. This suggests that the Triple-P Positive Parenting Program may be beneficial to the attitudes of those parents of children with T1D diagnoses. Considering related studies, two studies that were conducted with the parents of children diagnosed with T1D are worthy of mention. In the randomized controlled study conducted by Westrupp et al. (30) in 2015 with 76 parents, it was found that there were significant changes in the Over Reactivity subdimension of the Parenting scale after the Triple P-Positive Parenting Program. In another study conducted by Doherty et al. (31), it was determined that there were positive differences in the attitudes of parents after the Triple P-Positive Parenting Program applied to those parents of adolescents aged 11-17 years with T1D. These results indicate that the Triple P-Positive Parenting Program reduces behavioural disorder (32), attention deficit and hyperactivity disorder (34), anxiety disorder (33), and dysfunctional parenting practices such as sending the child to a Montessori school (35) and also increases positive or democratic parental attitudes.

In our study, there was a significant decrease in the SDQ scores of children after the Triple P-Positive Parenting Program. This shows that the Triple-P Positive Parenting
Program applied to the parents of children with T1D diagnosis reduces the emotional and behavioural problems of the children. This finding is similar to that in the study conducted by Westrupp et al. (30) in 2015 and Doherty et al. (31) in 2013 with the parents of children diagnosed with T1D. In both studies, the problematic behaviour of children and adolescents were found to decrease after the Triple-P Positive Parenting Program.

Our study findings show similarity with those obtained in other studies conducted on the Triple P Program with different samples and by using SDQ $(32,40-44)$. In the study conducted by Arkan (32), which was the first study on the Triple P-Positive Parenting Program in Turkey, in the study conducted by Özyurt (33) with the parents of children diagnosed with anxiety disorder, in the randomized controlled study conducted by Martin and Sanders (41) in 2003, in the randomized controlled study conducted by Leung et al. (43) in 2003 with 69 parents, in the study conducted by Stallman and Ralph (45) in 2007, and in the study conducted by Sanders et al. (42), which was initiated as a large project in 2008 and conducted with 2,996 parents, it was found that the total score of the children and adolescents from the difficulty subdimension of SDQ decreased as was also the case in our study. When the findings of these studies and our study are evaluated together, it is suggested that the Triple P-Positive Parenting Program is an effective and successful parent program in reducing children's behavioural and sensory problems. Considering that the Triple-P Positive Parenting Program improves parents' self-efficacy, self-efficiency, and selfcontrol characteristics, it is very important to shape the behaviours of parents and children together, strengthen the self-efficacy perceptions of parents, and develop the selfregulation skills of parents in the treatment of behavioural and emotional problems of children and adolescents $(22,42,46)$.

Another important finding regarding parents was that their General Health Questionnaire score was lower after the Triple-P Positive Parenting Program. This result shows that the stress and anxiety levels of the parents decreased significantly after the program. Westruppet et al. (30) evaluated the stress, anxiety and depression levels of parents before and after the program separately and reported that the anxiety and stress levels of parents decreased noticeably. In the study conducted by Doherty et al. (31) in 2013, there was no statistically significant difference found in the stress levels of parents after the program. Contrary to the study conducted by Doherty et al. (31), regarding the studies conducted on the Triple P Program with different 
samples in the world (47-49) and in Turkey (32-35), it is seen that the program reduces parents' stress, anxiety, and depression levels. It is clearly seen that the Triple-P Positive Parenting Program is more successful in reducing parents' stress, anxiety, and depression levels compared to other parent programs. This can be explained by the fact that the Triple P-Positive Parenting Program meets mostly parents' needs and strengthens parents more.

One important finding obtained in our study is that the program reduces the tendency to have conflict both in parents and children and reduces the level of family conflicts. This finding is similar to those in two studies conducted on the Triple P-Positive Parenting Program. In the studies conducted by Westrupp et al. (30) in 2015 and Doherty et al. (31) in 2013, the characteristics and quantity of family conflict were evaluated with the Diabetes Family Conflict scale. In both studies, it was revealed that there was a significant difference in the level of conflict after the program. Conflicts between the parents and the child affect the treatment management of the child with T1D negatively. Ending or reducing family conflicts is of great importance for successful treatment management. These results reveal that the Triple P-Positive Parenting Program is highly effective in reducing the parents' tendency to engage in conflict with each other and also in reducing family conflicts.

Another finding obtained in our study is that there was no significant difference in the HbA1C values of children before and after the Triple P-Positive Parenting Program. This result is similar to those obtained in the studies conducted by Westrupp et al. (30) in 2015 and Doherty et al. (31) in 2013. In both studies, it was found that there was no difference in the $\mathrm{HbA} 1 \mathrm{C}$ values of children at the $3^{\text {rd }}, 6^{\text {th }}$, and $12^{\text {th }}$ month follow-ups after the program. Both in our study and in the studies conducted by Westrupp et al. (30) and Doherty et al. (31), there was a decrease in the HbA1C values of children; however, this decrease was not found to be statistically significant.

\section{Study Limitations}

This study is important since it is the first study conducted in Turkey in which the Triple P-Positive Parenting Program was applied to the parents of children diagnosed with T1D. However, besides the positive results revealed, there are some limitations of the study. The main limitation is the small sample size. Another limitation is the lack of a randomized controlled study design. In light of these preliminary results, future studies should be planned with a randomly selected control group in order to show the effectiveness of this parent program more strongly. In addition, if possible, another parent program should be applied to the control group in our country. The third most important limitation is that no follow-up process was planned in order to demonstrate the permanence of the positive and healing effect of the program. Future studies or a study with the current sample group should be planned with at least a 6-month or 1-year follow-up. This is important in terms of showing the long-term efficacy determined in the literature for the Turkish sample.

\section{Conclusion}

In conclusion, it was determined that the Triple P-Positive Parenting Program reduced the General Health Questionnaire and PARI scores of the parents and the SDQ and Conflict Behaviour Assessment Questionnaire scores of the children with T1D. In addition, the parents' level of satisfaction with the program was high. Due to the many factors affecting the $\mathrm{HbA} 1 \mathrm{C}$ level, the decrease in the $\mathrm{HbA} 1 \mathrm{C}$ value of the children was not at the desired level. These results show that the Triple P-Positive Parenting Program applied to the parents positively contributes to the mental health of the family. Therefore, it is recommended to plan new studies with a randomized controlled study design and a larger sample, in which prospective follow-up sessions are planned, to conduct research in which the results of the Triple P-Positive Parenting Program and currently applied programs in our country are compared, and to extend this program throughout the country.

\section{Ethics}

Ethics Committee Approval: The Ethics Committee approval of this study was received on 30.07.2013 from Bursa Uludağ University Hospital Clinical Research Ethics Committee (2013-14/19).

Informed Consent: Written, informed consent was obtained from all parents.

Peer-review: Externally peer-reviewed.

\section{Authorship Contributions}

Surgical and Medical Practices: B.A., A.P.V., Ş.E., E.E., Concept: B.A., A.P.V., Ş.E., E.E., Design: B.A., A.P.V., Ş.E., E.E., Data Collection or Processing: B.A., Analysis or Interpretation: B.A., Literature Search: B.A., A.P.V., Ş.E., E.E., Writing: B.A., A.P.V., Ş.E., E.E.

Conflict of Interest: No conflict of interest was declared by the authors.

Financial Disclosure: The authors declared that this study received no financial support. 


\section{References}

1. Isaacs D, Sewell IR. Children with choronic conditions. The Medical Journal of Australia 2003; 179:235-6.

2. Vickers M, Parris M, Bailey J. Working mothers of children with choronic illness: Narratives of working and caring. Australian Journal of Early Childhood 2004; 29:39-44.

3. Lohan A, Morawska A, Mitchell A. A systematic review of parenting interventions for parents of children with type 1 diabetes. Child: Care, Health and Development 2015; 41:803-17.

4. Kish AM, Newcombe PA, Haslam DM. Working and caring for a child with chronic illness: A review of current literatüre. Child Care Health Dev 2018; 44:343-54.

5. Patterson CC, Dahlquist GG, Gyürüs E, Green A, Soltész C. Incidence trends for childhood type 1 diabetes in Europe during 1989-2003 and predicted new cases 2005-20: a multicentre prospective registration study. The Lancet 2009; 373:2027-33.

6. International Diabetes Federation. IDF Diabetes Atlas, 3rd edn. Brussels: International Diabetes Federation; 2006. Available at: http://www. diabetesatlas.org/resources/previous-editions. html. Accessed 1 July 2019.

7. Lohan A, Mitchell A, Filus A, Sofronof K, Morawska. Positive Parenting for healty living (Triple P) for parents of children with type 1 diabetes: protocol of a randomised controlled trial. BMC Pediatrics 2016; 16:1-13.

8. Lohan A, Morawska A, Mitchell A. Development and Validation of a Measure Assessing Child Diabetes Behavior: The Diabetes Behavior Checklist Comprehensive Child and Adolescent Nursing 2018; 41:111-27.

9. Lohan A, Morawska A, Mitchell A. Associations Between Parental Factors and Child Diabetes-Management-Related Behaviors. Journal of Developmental \& Behavioral Pediatrics 2017; 38:330-8.

10. Canter K, Christofferson I, Scialla AM, Kazak AE. TechnologyFocused Family Interventions in Pediatric Chronic Illness: A Systematic Review. Journal of Clinical Psychology in Medical Settings 2019; 26:68-87.

11. Markowitz IT, Garvey KC, Laffel LMB. Developmental changes in the roles of patients and families in type 1 diabetes management. Curr Diabetes Rev 2015; 11:231-8.

12. Hilliard ME, Tully C, Monaghan M, Wang J, Streisand R. Design and development of a stepped-care behavioral intervention to support parents of young children newly diagnosed with type 1 diabetes, Contemporary Clinical Trials 2017; 62:1-10.

13. Feldman MA, Anderson L, Shapiro JB, Jedraszko AM, Evans M, Weil LEG, Garza KP, Weissberg-Benchell J. Family-Based Interventions Targeting Improvements in Health and Family Outcomes of Children and Adolescents with Type 1 Diabetes: A Systematic Review, Current Diabetes Reports 2018; 18:15.

14. Palmer DL, Osborn P, King PS, et al. The structure of parental involvement and relations to disease management for youth with type 1 diabetes. I Pediatr Psychol 2011; 36:596-605.

15. Davis $\mathrm{CL}$, Delamater $\mathrm{AM}$, Shaw $\mathrm{KH}$, et al. Parenting styles, regimen adherence, and glycemic control in 4- to 10-year-old children with diabetes. Journal of Pediatric Psychology 2001; 26:123-9.

16. Liakopouloua M, Alifierakia T, Katidenioua A, et al. Maternal expressed emotionandmetaboliccontrolofchildren and adolescents with diabetes mellitus. Psychotherapy and Psychosomatics 2001; 70:78-85.

17. Shorer M, David R, Schoenberg-Taz M, Levavi-Lavi I, Phillip M, Meyerovitch J. Role of parenting style in achieving metabolic control in adolescents with type 1 diabetes. Diabetes Care 2011; 34:1735-37.

18. Miller-Johnson S, Emery RE, Marvin RS, Clarke W, Lovinger R, Martin M. Parent-child relationships and the management of insulin-dependent diabetes mellitus. Journal of Consulting and Clinical Psychology 1994; 62:603.

19. Chisholm V, Atkinson L, Bayrami L, Noyes K, Payne A, Kelnar C. An exploratory study of positive and incongruent communication in young children with type 1 diabetes and their mothers. Child: Care, Health and Development 2012; 40:85-94.

20. Mullett J. Triple P Community Implementation Report. Victoria, BC: Action Research Consulting. Report prepared for the Vancouver Island Health Authority 2007.

21. Sanders MR. Development, evaluation, and multinational dissemination of the Triple P-Positive Parenting Program. Annu Rev Clin Psychol 2012; 8:345-79.

22. Sanders MR. Triple P-Positive Parenting Program: Towards an empirically validated multilevel parenting and family support strategy for the prevention of behavior and emotional problems in children. Clin Child Fam Psychol Rev 1999; 2:71-90.

23. Sanders MR. Guest editorial: the translation of an evidencebased parenting program into regular clinic services. Australian e-Journal for the Advancement of Mental Health 2003; 2.

24. Sanders MR. Triple P-positive parenting program as a public health approach to strengthening parenting. I Fam Psychol 2008; 22:506-17.

25. Sanders MR, Kirby JN, Tellegen CL, Day JJ. Towards a public health approach to parenting: A systematic review and metaanalysis of the Triple P-Positive Parenting Program. Clin Psychol Rev 2014; 32:337-57.

26. De Graaf I, Speetjens P, Smit F, de Wolff M, Tavecchio L. Effectiveness of the Triple P Positive Parenting Program on behavioral problems in children: a meta-analysis. Behav Modif 2008; 32:714-35.

27. De Graaf I, Speetjens P, Smit F, De Wolff M, Tavecchio L. Effectiveness of the triple $P$ positive parenting program on parenting: a meta- analysis. Fam Relat 2008; 57:553-66.

28. Nowak C, Heinrichs NA. comprehensive meta-analysis of triple P-positive parenting program using hierarchical linear modeling: effectiveness and moderating variables. Clin Child Fam Psychol Rev 2008; 11:114-44.

29. Sanders MR, Turner KM, Markie-Dadds C. The development and dissemination of the Triple P-Positive Parenting Program: A multilevel, evidence-based system of parenting and family support. Prev Sci 2002; 3:173-89.

30. Westrupp EM, Northam E, Lee KJ, Scratch SE, Cameron F. Reducing and preventing internalizing and externalizing behavior problems in children with type 1 diabetes: a randomized controlled trial of the Triple P-Positive Parenting Program. Pediatric Diabetes 2015; 16:554-63.

31. Doherty FM, Calam R, Sanders MR. Positive parenting program (Triple P) for families of adolescents with type 1 diabetes: a 
randomized controlled trial of self-directed teen triple P. J Pediatr Psychol 2013; 38:846-58.

32. Arkan B, Davranış Sorunları Olan Ergenlerin Ebeveynlerine Uygulanan Eğitimin Ebeveyn Tutumu, Ebeveyn Ruh Sağlığı ve Ergen Davranışına Etkisi Dokuz Eylül Üniversitesi Sağlık Bilimleri Enstitüsü Psikiyatri Hemşireliği Anabilim Dalı Doktora Tezi İzmir 2012.

33. Özyurt G. Triple P Olumlu Anne Babalık Eğitimi'nin Anksiyete Bozukluğu Olan 8-12 Yaş Arası Çocuklarda Ve Ebeveynlerinde Anksiyete Düzeyi Ve Ruh Sağlığı Üzerine Etkilerinin Araştırıldığı Randomize Kontrollü Bir Çalışma, Dokuz Eylül Üniversitesi Tıp Fakültesi Çocuk Ve Ergen Ruh Sağlığı Ve Hastalıkları Anabilim Dalı, Uzmanlık Tezi, İzmir, 2013

34. Öztürk Y. Triple P Olumlu Anne Babalık Eğitimi'nin Dikkat Eksikliği Ve Hiperaktivite Bozukluğu Olan 7-12 Yaş Arası Çocuklarda Dikkat Eksikliği Hiperaktivite Bozukluğu Belirtileri Üzerine Etkilerinin Araştırıldığı Randomize Kontrollü Bir Çalışma. Dokuz Eylül Üniversitesi Tıp Fakültesi Çocuk Ve Ergen Ruh Sağlığı Ve Hastalıkları Anabilim Dalı, Uzmanlık Tezi, İzmir, 2013.

35. Arkan B. Olumlu Annebabalık Eğitimi Programı́nın (Positive Parenting Program-Triple P) Ailenin Ruh Sağlığına Etkisi. Bursa Uludağ Üniversitesi Eğitim Fakültesi Dergisi 2019; 32:43-61.

36. Le Compte G, Le Compte A, Özer S. Üç Sosyoekonomik Düzeyde Ankaralı Annelerin Çocuk Yetiştirme Tutumları: Bir Ölçek Uyarlaması. Türk Psikoloji Dergisi 1978; 1:5-8.

37. Güvenir $T$, Özbek A, Baykara B, Arkar $H$, Şentürk B, İncekaş S. Güçler ve güçlükler anketi'nin (GGA) türkçe uyarlamasının psikometrik özellikleri. Çocuk ve Ergen Ruh Sağlığı Dergisi 2008; 15:65-74.

38. Kilic C. Genel Sağıık Anketi: geçerlik ve güvenirlik çalışması. Türk Psikiyatri Dergisi 1996; 7;3-11.

39. Sanders MR, Ralph A, Thompson R, Sofronoff $K$, Gardiner $P$, Bidwell K, Dwyer S. Every Family: A Public Health Approach to Promoting Children's Wellbeing. Brief Report. www.pfsc. uq.edu.au, 2005: Erişim Tarihi: 12. 01. 2008.

40. Sanders MR, Montgomery DT, Brechman-Toussaint ML. The Mass Media and The Prevention of Child Behavior Problems: The Evaluation of A Television Series To Promote Positive Outcomes For Parents And Their Children. Journal of Child Psychology and Psychiatry 2000; 41:939-48.
41. Martin Al, Sanders MR. Balancing Work and Family: A Controlled Evaluation of the Triple P- Positive Parenting Program as a WorkSite Intervention. Child and Adolescent Mental Health 2003; 8:161-9.

42. Sanders MR, Ralph A, Sofronoff K, Gardiner P, Thompson R, Dwyer S, Bidwell K. Every Family: A Population Approach To Reducing Behavioral And Emotional Problems In Children Making The Transition To School. Journal of Primary Prevention 2008; 29:197-222.

43. Leung C, Sanders MR, Leung S, Mak R, Lau J. An Outcome Evaluation of The Implementation of The Triple P- Positive Parenting Program In Hong Kong. Family Process 2003; 42:53144

44. Turner KMT, Richards M, Sanders MR. Randomised clinical trial of a group parent education programme for Australian Indigenous families. I Paediatr Child Health 2007; 43:429-37.

45. Stallman HM, Ralph A. Reducing Risk Factors For Adolescent Behavioural And Emotional Problems: A Pilot Randomised Controlled Trial of A Self-Administered Parenting Intervention. Australian e-Journal for the Advancement of Mental Health 2007; 6:1-13

46. Sanders MR, Markie-Dadds C, Turner KMT, Ralph A. Using the Triple P System of Intervention to Prevent Behavioural Problems in Children and Adolescents. Handbook of Interventions that Work with Children and Adolescents Prevention and Treatment. John Wiley \& Sons Ltd 2004; 490-516.

47. Zubrick SR, Ward KA, Silburn SR, Lawrence D, Williams AA, Blair E, Robertson D, Sanders MR. Prevention of Child Behavior Problems Through Universal Implementation of A Group Behavioral Family Intervention. Prevention Science 2005; 6:287304.

48. Leung C, Sanders MR, Ip F, Lau J. Implementation of Triple P Positive Parenting Program In Hong Kong: Predictors of Program Completion And Clinical Outcomes. Journal of Children's Services 2006; 1:4-17.

49. Bodenmann G, Cina A, Ledermann T, Sanders MR, The Efficacy of The Triple $\mathrm{P}$ - Positive Parenting Programme In Improving Parenting And Child Behaviour: A Comparison With Two Other Treatment Conditions. Behaviour Research and Therapy 2008; 46:411-27. 